\title{
Silicon in broiler drinking water promotes bone development in broiler chickens
}

\author{
S. Sgavioli, C. H. de Faria Domingues, D. M. C. Castiblanco, M. F. F. M. Praes, \\ Giuliana M. Andrade-garcia, E. T. Santos, S. M. Baraldi-Artoni, R. G. Garcia \& \\ O. M. Junqueira
}

To cite this article: S. Sgavioli, C. H. de Faria Domingues, D. M. C. Castiblanco, M. F. F. M. Praes, Giuliana M. Andrade-garcia, E. T. Santos, S. M. Baraldi-Artoni, R. G. Garcia \& O. M. Junqueira (2016) Silicon in broiler drinking water promotes bone development in broiler chickens, British Poultry Science, 57:5, 693-698, DOI: 10.1080/00071668.2016.1206190

To link to this article: https://doi.org/10.1080/00071668.2016.1206190

Accepted author version posted online: 29

Jun 2016.

Published online: 23 Sep 2016.

Submit your article to this journal $₫$

Џ Article views: 218

View Crossmark data \lceil

Citing articles: 1 View citing articles ๘ 


\title{
Silicon in broiler drinking water promotes bone development in broiler chickens
}

\author{
S. SGAVIOLI, C. H. DE FARIA DOMINGUES ${ }^{1}$, D. M. C. CASTIBLANCO ${ }^{1}$, M. F. F. M. PRAES ${ }^{1}$, \\ GIULIANA M. ANDRADE-GARCIA ${ }^{1}$, E. T. SANTOS $^{1}$, S. M. BARALDI-ARTONI ${ }^{1}$, R. G. GARCIA, \\ AND O. M. JUNQUEIRA ${ }^{2}$
}

College of Agricultural Sciences, Federal University of Grande Dourados, Dourados, Brazil, ${ }^{1}$ Department of Morphology and Animal Physiology, São Paulo State University, Jaboticabal, Brazil, and ${ }^{2}$ Regional Jatai, College of Agricultural Sciences, Federal University of Goiás, Jatai, Brazil

\begin{abstract}
Skeletal abnormalities, bone deformities and fractures cause significant losses in broiler production during both rearing and processing. Silicon is an essential mineral for bone and connective tissue synthesis and for calcium absorption during the early stages of bone formation.

2. Performance was not affected by the addition of silicon. However, broilers receiving silicon showed a significant increase of phosphorus, zinc, copper, manganese and ash in the tibia.

3. In conclusion, broiler performance was not impaired by adding the tested silicon product to the drinking water. In addition, bone development improved, as demonstrated by higher mineral and ash content.

4. Further studies are required to determine the optimal concentration of silicon, including heat stress simulations, to better understand the effects of silicon on bone development.
\end{abstract}

\section{INTRODUCTION}

The fast growth rate of broilers and high meat deposition lead to increased levels of some metabolic disorders causing leg problems, also called leg weakness, and locomotor problems ( $\mathrm{Su}$ et al., 1999, Nääs et al., 2012). Deformations and fractures are serious problems in broilers. Fractures are related to low levels of feed conversion, due to limited mobility, causing limitations in the feed and water intake, which results in lower weight gain. These birds should be killed to avoid damage to the flock (Almeida Paz et al., 2008). The leg problems of broilers have a direct relationship with the increase in weight gain. A better weight gain is the ultimate goal of broiler production. The occurrence of these diseases is responsible for significant losses in global poultry production. Recent research estimates that these bone disorders result in mortality rates between $2 \%$ and $8 \%$ in broiler production, and the highest incidence are in broilers, at $7-8$ weeks of age (Junior, 2009).

Silicon is an important component of bone formation, and its deficiency affects skeletal development (Schwarz and Milne, 1972). Silicon in bones and cartilage is involved in the synthesis of the bone matrix, and significantly influences bone calcification (Seaborn and Nielsen, 1994). In rats, silicon supplementation was found to increase bone metabolism (Seaborn and Nielsen, 1994), and Jugdaohsingh et al. (2004) verified that silicon intake had a positive effect on human bone mineral density. These studies suggest that silicon may also play an important role in broilers.

Bone deformities and fractures occurring during the rearing period result in considerable losses for the poultry industry. When this is associated with infections, mortality rates increase, productivity is reduced, and carcass downgrade rates increase. In addition, market-age broilers with bone weakness or deformities may suffer

Correspondence to: Sarah Sgavioli, College of Agricultural Sciences, Federal University of Grande Dourados, Dourados-Itahum, km 12, Postal Code: 533, CEP: 79.804-970, Dourados, MS, Brazil. E-mail: rodrigogarcia@ufgd.edu.br

Accepted for publication 28 April 2016 
fractures during catching and transport, causing processing losses.

Experiments carried out with broilers (Carlisle, 1972, 1981; Elliot and Edwards, 1991; Sahin et al., 2006) show that silicon plays an essential physiological role in bone formation. However, there are few studies on silicon supplementation, particularly through drinking water. Therefore, the effect of this mineral on broiler performance, as well as on broiler bone development and growth, needs further study.

The objective of this study was to evaluate the effects of various added silicon concentrations in broiler drinking water on performance, bone density, bone breaking strength and bone ash profile in the tibia of 1-49-d-old broilers.

\section{MATERIALS AND METHODS}

This experiment was approved by the Animal Ethics Committee (CEUA) of the College of Agriculture and Veterinary Sciences of the São Paulo State University (UNESP - Jaboticabal), Jaboticabal, SP Brazil, protocol number 004732/13.

\section{Birds, housing and experimental design}

In the trial, 1120-d old, male, Cobb ${ }^{\circledR}$ broiler chicks were housed in 32 pens with 35 birds each until the 49 th $\mathrm{d}$ of age. The birds were distributed in to a completely randomised experimental design, with 4 silicon levels $(0,0.5,1.0$ or $1.5 \mathrm{mg}$ of the commercial product/100 kg body weight (BW)/ d). The commercial product contained $30 \mathrm{~g}$ silicon/1 of solution.

The birds received feed and water ad libitum during the entire experimental period and thermal comfort was maintained using brooders and side-curtain ventilation. The chicks were vaccinated in the hatchery against Marek's disease, infectious bursal disease (IBD) and Avian pox. The following vaccination programme was completed during the experimental period: IBD (mild strain) on d 7 via eye drops; Newcastle disease and IBD (hot strain) via drinking water, using powdered milk as vehicle $\left(2 \mathrm{~g} \mathrm{l}^{-1}\right)$ on $\mathrm{d} 14$.

Temperature and relative humidity were recorded daily using two digital thermo-hygrometers placed at bird height in two equidistant locations. The average and absolute maximum temperatures was $30^{\circ} \mathrm{C}$ and $34.1^{\circ} \mathrm{C}$, respectively, while the average and absolute minimum temperatures recorded were $18.6^{\circ} \mathrm{C}$ and $13.4^{\circ} \mathrm{C}$, respectively. The average and absolute maximum relative humidity was $73.36 \%$ and $36.18 \%$, and the average and absolute minimum relative humidity was $27.82 \%$ and $15.00 \%$, respectively.

Diets were maize and soybean meal based (Table 1) and formulated for starter (1-21 d), grower (22-42 d) and finisher (43-49 d) phases,

Table 1. Ingredients and nutritional composition of the experimental diets

\begin{tabular}{|c|c|c|c|}
\hline & \multicolumn{3}{|c|}{ Phases } \\
\hline & Starter (1-21-d old) & Grower (22-42-d old) & Finisher (43-49-d old) \\
\hline \multicolumn{4}{|l|}{ Ingredients $(\mathrm{g} / \mathrm{kg})$} \\
\hline Maize meal & 584 & 620 & 707 \\
\hline Soybean meal & 362 & 303 & 260 \\
\hline Soybean oil & 10.0 & 39.5 & 3.7 \\
\hline Dicalcium phosphate & 20.0 & 16.3 & 16.0 \\
\hline Calcitic limestone & 9.0 & 8.3 & 7.0 \\
\hline DL-methionine & 3.0 & 1.2 & 1.3 \\
\hline L-lysine $\mathrm{HCl}$ & 2.0 & 2.2 & - \\
\hline Nutritional supplement* & 5.0 & 5.0 & 1.0 \\
\hline Sodium chloride & 5.0 & 4.5 & 4.0 \\
\hline \multicolumn{4}{|l|}{ Calculated nutritional composition } \\
\hline Crude protein & 215 & 191 & 180 \\
\hline Metabolisable energy (MJ/kg) & 12.14 & 13.23 & 12.64 \\
\hline Calcium & 9.60 & 8.20 & 7.80 \\
\hline Sodium & 2.30 & 2.20 & 2.20 \\
\hline Available phosphorus & 4.80 & 4.00 & 4.00 \\
\hline Methionine + cystine digestible & 9.20 & 6.10 & 6.00 \\
\hline Methionine digestible & 5.30 & 2.80 & 2.70 \\
\hline Lysine digestible & 12.00 & 10.70 & 8.60 \\
\hline Threonine digestible & 7.30 & 6.50 & 1.90 \\
\hline Tryptophan digestible & 2.00 & 2.20 & 1.70 \\
\hline Isoleucine digestible (\%) & 8.50 & 7.40 & 6.80 \\
\hline
\end{tabular}

*Nutrients per $\mathrm{kg}$ of diet: Starter phase from 1 to $21 \mathrm{~d}$ - retinol $2.7 \mathrm{mg}$, cholecalciferol $92 \mu \mathrm{g}$, $\alpha$-tocopherol $15 \mathrm{mg}$, vitamin $\mathrm{K} 32.50 \mathrm{mg}$, thiamin $1.5 \mathrm{mg}$, riboflavin $5.01 \mathrm{mg}$, pyridoxine $1.5 \mathrm{mg}$, vit. B12 $12 \mu \mathrm{g}$, folic acid $0.6 \mathrm{mg}$, biotin $0.05 \mathrm{mg}$, niacin $35 \mathrm{mg}$, calcium pantothenate $11.22 \mathrm{mg}$, copper $6 \mathrm{mg}$, cobalt $0.10 \mathrm{mg}$, iodine $1.02 \mathrm{mg}$, iron $50 \mathrm{mg}$, manganese $65 \mathrm{mg}$, zinc $45 \mathrm{mg}$, selenium $0.21 \mathrm{mg}$, choline chloride (50\%) $700 \mathrm{mg}$, coccidiostat $80 \mathrm{mg}$, growth promoter (zinc bacitracin) $80 \mathrm{mg}$, and antioxidant (52.8\%) $12 \mathrm{mg}$. Grower and Finisher phases 22-49 d - retinol $2.4 \mathrm{mg}$, cholecalciferol $89 \mu \mathrm{g}$, $\alpha$-tocopherol $12 \mathrm{mg}$, vitamin K3 $2 \mathrm{mg}$, thiamin $1 \mathrm{mg}$, riboflavin $4.02 \mathrm{mg}$, pyridoxine $1.02 \mathrm{mg}$, vit. b12 $10.02 \mu \mathrm{g}$, folic acid $0.402 \mathrm{mg}$, biotin $0.042 \mathrm{mg}$, niacin $28.02 \mathrm{mg}$, calcium pantothenate $11.22 \mathrm{mg}$, copper $6 \mathrm{mg}$, cobalt $0.102 \mathrm{mg}$, iodine $1.02 \mathrm{mg}$, iron $50 \mathrm{mg}$, manganese $65 \mathrm{mg}$, zinc $45 \mathrm{mg}$, selenium $0.21 \mathrm{mg}$, choline chloride (50\%) $500 \mathrm{mg}$, coccidiostat $60 \mathrm{mg}$, growth promoter (zinc bacitracin) $60 \mathrm{mg}$, and antioxidant $(57.8 \%) 12 \mathrm{mg}$. 
according to the recommendations of Rostagno et al. (2005).

\section{Performance}

At the end of the experimental period ( $49 \mathrm{~d}$ ), the weight gain, feed intake and feed conversion ratio were calculated. The birds, the offered feed and the feed residue were weighed at the beginning and end of the starter (1-21 d), grower (22-42 d) and finisher (43-49 d) periods. Water consumption was calculated as the difference between the supplied volume and the leftover volume from the 1 st to 21 st $d$ of age. Mortality was recorded daily for the correction of performance parameters and to calculate viability.

\section{Bone densitometry}

On the 49th d, 32 birds (one bird per pen, 8 birds per treatment) with body weights close to the experimental unit's average body weight, were selected and identified with numbered leg bands. The selected birds fasted $8 \mathrm{~h}$ and then were killed by neck dislocation, bled, plucked and eviscerated. The left and right tibiae of each bird were removed and marked.

Bone densitometry was performed on the left tibia. Muscles, cartilage and the fibula were removed prior to the densitometry evaluation. The evaluation was performed with the assistance of an aluminium step wedge (6063 alloy, ABNT) with 12 steps. Steps $1-10$ were $0.5 \mathrm{~mm}$ thick. Steps 11 and 12 were $0.6 \mathrm{~mm}$ and $8.0 \mathrm{~mm}$ thick, respectively. Each step measured $5 \times 25 \mathrm{~mm}^{2}$, and the scale was radiographed together with the bones.

The scale was placed parallel to the bone, with the highest steps at the top of the frame. The X-ray equipment was calibrated using the technique relating kilovoltage $(\mathrm{kV})$, milliamperage $(\mathrm{mA})$ and milliamperage-second (mAs) with the thickness of the analysed bone area. A standard X-ray machine (Siemens, Model Tridoro 812 E) from the radiology department of the Veterinary Hospital at the College of Agriculture and Veterinary Sciences of the São Paulo State University (UNESP - Jaboticabal), Jaboticabal, SP Brazil, was calibrated at $30 \mathrm{kV}, 400 \mathrm{~mA}$ and $4 \mathrm{mAs}$. The bones were radiographed using Kodak PMATG/RA film and $18 \times 24 \mathrm{~cm}^{2}, 24 \times 30 \mathrm{~cm}^{2}$ and $30 \times 40 \mathrm{~cm}^{2}$ frames. The metal frame was set with intensifying screens (Kodak, Lanex Regular). Bones were placed $2 \mathrm{~cm}$ distant from the borders of the frame to allow uniform penetration of the X-rays. The film was previously identified by light impression, then developed and fixed in an automatic processor (Kodak X-OMAT 200).

Densitometry was by use of a digital scanner (Scanion A3). The digitised images were analysed using the Image-Pro Plus software program (Image-
Pro Plus, Media Cybernetics, version 4.1) calibrated for bone mineral density. Bone mineral density of the following regions was calculated: proximal epiphysis, diaphysis and distal epiphysis. Values were expressed as millimetres of aluminium $(\mathrm{mm} \mathrm{Al})$.

\section{Bone breaking strength}

Next, the tibia samples used for measuring bone densitometry were evaluated for breaking strength. Eight left tibial samples per treatment were analysed. The bones were placed in a texture analyser (TA-XT2i) coupled with a Warner-Bratzler apparatus (straight blade) perpendicular to the blade. The maximum strength applied to the bones immediately before they broke was considered the breaking strength and was expressed in Newton (N).

\section{Mineral profile}

Calcium, phosphorus, zinc, copper, manganese and ash content were measured in the right tibias. The right tibias from the different treatments were identified using numbered aluminium plates. The soft tissue was removed and the bones boiled in deionised water for 5 minutes. After drying at environmental temperature, the samples were immersed in petroleum ether for $48 \mathrm{~h}$, dried in a forced-ventilation oven at $60^{\circ} \mathrm{C}$ for $48 \mathrm{~h}$ and then ground in a ball mill. Bone mineral content was analysed at the Feed Analysis Laboratory of the College of Agriculture and Veterinary Sciences of the São Paulo State University (UNESP - Jaboticabal), Jaboticabal, SP Brazil, using wet analyses. Ash content was determined by burning the samples at $600^{\circ} \mathrm{C}$. The methods were applied according to Silva and Queiroz (2002) and expressed as defatted dry matter.

\section{Statistical analysis}

Data were tested for the presence of outliers, "Studentised" residual normality and variance homogeneity. After complying with these assumptions, the data were submitted to analysis of variance $(5 \%$ significance level) using the General Linear Model $\left(\right.$ GLM) procedure of SAS ${ }^{\circledR}$ statistical package (SAS Institute, 2002). When means differed significantly by the $\mathrm{F}$ test, analysis orthogonal was performed to test the linear, quadratic and cubic effects of silicon concentrations on the evaluated parameters.

\section{RESULTS}

\section{Performance}

Performance was not influenced by silicon concentrations in the drinking water (Table 2). 
Table 2. Performance parameter for broilers at $49 \mathrm{~d}$ (means and corresponding standard error of the mean)

\begin{tabular}{lcccc}
\hline & & & Feed \\
Silicon levels & $\begin{array}{c}\text { Weight } \\
\text { gain }(\mathrm{g})\end{array}$ & $\begin{array}{c}\text { Feed } \\
\text { intake }(\mathrm{g})\end{array}$ & $\begin{array}{c}\text { conversion } \\
(\mathrm{g} / \mathrm{g})\end{array}$ & $\begin{array}{c}\text { Water } \\
\text { intake }(\mathrm{l})\end{array}$ \\
\hline $0 \mathrm{mg}$ & 3168 & 5807 & 1.83 & 2.4 \\
$0.5 \mathrm{mg}$ & 3160 & 5788 & 1.83 & 2.5 \\
$1.0 \mathrm{mg}$ & 3200 & 5896 & 1.86 & 2.4 \\
$1.5 \mathrm{mg}$ & 3152 & 5769 & 1.83 & 2.4 \\
SE & 26.09 & 47.78 & 0.01 & 0.03 \\
Quadratic & 0.2301 & 0.1575 & 0.6091 & 0.8067 \\
$\quad$ probability & & & & \\
Linear & 0.1432 & 0.1471 & 0.3280 & 0.6300 \\
$\quad$ probability & \multicolumn{5}{c}{} & & \\
\hline
\end{tabular}

Probability: $P<0.05$

\section{Bone densitometry and breaking strength}

Data in Table 3 show that the concentrations of silicon in the drinking water had no effect on distal or proximal epiphysis bone density and breaking strength.

\section{Mineral profile}

The silicon product levels significantly influenced $(P<0.05)$ bone phosphorus, zinc, manganese and ash content (Table 4). There was a quadratic effect $(P<0.05)$ on phosphorus and zinc content, with maximum levels of these minerals obtained

Table 3. Tibia densitometry and bone strength for broilers at $49 d$ (means and corresponding standard error of the mean)

\begin{tabular}{lllc}
\hline & $\begin{array}{c}\text { Proximal } \\
\text { epiphysis } \\
(\mathrm{mm} \mathrm{Al})\end{array}$ & $\begin{array}{c}\text { Distal epiphysis } \\
(\mathrm{mm} \mathrm{Al})\end{array}$ & $\begin{array}{c}\text { Breaking } \\
\text { strength (kgf) }\end{array}$ \\
\hline Silicon levels & 3.517 & 2.067 & 33.06 \\
$0 \mathrm{mg}$ & 3.110 & 1.558 & 31.57 \\
$0.5 \mathrm{mg}$ & 3.807 & 1.938 & 27.57 \\
$1.0 \mathrm{mg}$ & 3.365 & 1.975 & 32.86 \\
$1.5 \mathrm{mg}$ & 0.2 & 0.2 & 1.3 \\
SE & 0.4308 & 0.9751 & 0.0761 \\
Quadratic & & & 0.5363 \\
$\quad$ probability & 0.9336 & 0.8276 & \\
Linear & & & \\
probability & & \multicolumn{3}{c}{} \\
\hline
\end{tabular}

Probability: $P<0.05$ at silicon product concentrations of 0.97 and $1.23 \mathrm{mg} / 100 \mathrm{~kg} \mathrm{BW} / \mathrm{d}$, respectively, as calculated by the equations, $\mathrm{P}=-1.2 \mathrm{x}^{2}+2.336 \mathrm{x}+10.818$ $\left(R^{2}=0.82\right)$ and $\mathrm{Zn}=-11.12 \mathrm{x}^{2}+27.264 \mathrm{x}+168.23$ $\left(R^{2}=0.88\right)$. Inclusion of the silicon had a linear positive effect $(P<0.05)$ on bone ash and manganese content. According to the following equations: $\mathrm{Ash}=2.696 \mathrm{x}+59.218\left(R^{2}=0.91\right)$ and $\mathrm{Mn}=1.956 \mathrm{x}+11.078\left(R^{2}=0.95\right)$, the highest silicon level $(1.5 \mathrm{mg} / 100 \mathrm{~kg} \mathrm{BW} / \mathrm{d})$ resulted in the highest bone ash content and manganese concentration at $49 \mathrm{~d}$ of age.

\section{DISCUSSION}

Drinking water supplementation with the silicon product did not significantly affect broiler performance (feed and water intake, weight gain and feed conversion ratio). These results are consistent with the findings of Carlisle (1981), who also did not observe any effect of silicon supplementation on broiler performance. However, in an earlier study Carlisle (1972), feeding broilers a purified amino acid diet with a low silicon inclusion, observed slower $50 \%$ growth rate between weeks 2 and 3, as compared to those birds fed on the same feed, but with an increased silicon addition. Sahin et al. (2006) evaluated three dietary concentrations $(0,500$ or $1,000 \mathrm{mg} / \mathrm{kg})$ of an arginine, inositol and silicon complex in quails, and did not observe any impact on performance.

Silicon plays an important role in bone development and in the synthesis of cartilage and connective tissue. It participates in the cross links between collagen and proteoglycans. It is an important ion in osteoblasts of young animals, and its levels decline as calcium and phosphorus are deposited in the bones as the animals age. Bone deformities and fractures are severe health problems in modern, rapidly growing broilers, because the genetic improvement on performance has not included genetic improvement on bone development as well. Broilers with skeletal conditions have difficulty in reaching feeders and drinkers, which results in low feed intake and low

Table 4. Tibia mineral profile for broilers at $49 d$ (means and the corresponding standard error of the mean)

\begin{tabular}{|c|c|c|c|c|c|c|}
\hline \multirow[b]{2}{*}{ Silicon levels } & Calcium & Phosphorus & Ash & Zinc & Copper & Manganese \\
\hline & \multicolumn{3}{|c|}{$(\% / \mathrm{DM})$} & \multicolumn{3}{|c|}{$(\mathrm{mg} / \mathrm{kg} \mathrm{DM})$} \\
\hline $0 \mathrm{mg}$ & 22.8 & 10.7 & 59.1 & 169.3 & 5.6 & 11.1 \\
\hline $0.5 \mathrm{mg}$ & 23.2 & 11.9 & 60.4 & 175.9 & 5.7 & 11.9 \\
\hline $1.0 \mathrm{mg}$ & 22.4 & 11.7 & 62.7 & 187.5 & 5.8 & 13.4 \\
\hline $1.5 \mathrm{mg}$ & 23.0 & 11.7 & 62.7 & 183.1 & 5.5 & 13.5 \\
\hline $\mathrm{SE}$ & 0.31 & 0.32 & 0.87 & 3.89 & 0.08 & 0.58 \\
\hline Quadratic probability & 0.9358 & 0.0181 & 0.1056 & 0.0001 & 0.0624 & 0.1328 \\
\hline Linear probability & 0.8383 & 0.0597 & $<0.0001$ & 0.0003 & 0.7983 & $<0.0001$ \\
\hline
\end{tabular}

Probability: $P<0.05$ 
growth rates. Frequently, these birds must be killed. Considering the role silicon plays in bone development and the bone development problems found in broilers, this study evaluated the supplementation of a silicon product in broiler drinking water for its effect on bone density, breaking strength and mineral profile.

Although the silicon product supplementation did not affect bone density and tibial breaking strength, a higher mineral (P, Mn, Zn) and ash content was promoted by supplementation of the product, as previously found by Carlisle (1972), Schwarz and Milne (1972), Fiore et al. (2000), Clementi et al. (2001), Jugdaohsingh et al. (2004) and Sahin et al. (2006). However, in the aforementioned articles, silicon was added via feed, which is different from this study, where silicon was supplemented in the drinking water. Drinking water supplementation is easier and more accurate.

During inorganic bone matrix synthesis, calcium phosphate and other elements (bicarbonate, magnesium, potassium, sodium and citrate) are concentrated, forming hydroxyapatite crystals, which bind to collagen fibres, conferring strength and flexibility to the bones. Hydroxyapatite crystals are composed of calcium, phosphorus, sodium, magnesium, potassium, strontium, zinc, fluorine, chlorine and silicon. These are gradually released from the bone matrix and constantly resorbed, supplying metabolically important inorganic nutrients (Tucker, 2003), such as silicon, which varies with animal age and sex (Bissé et al., 2005).

Seaborn and Nielsen (1994) observed that silicon acts mainly in the synthesis of the bone matrix and may significantly improve bone calcification. Gough et al. (2004), in a study with broilers, found a significant increase in the regulation of osteoblast proliferation and in the gene expression of collagen type I synthesis in bone tissue when birds were fed on $0.5 \%$ silicon via feed. The authors of this study also observed a synergistic effect of silicon and calcium on the stimulation of bone cell activity when compared to control birds. Hing et al. (2005) explain that silicon is associated with calcium during the initial phase of bone formation and also binds to magnesium and fluorine, which is necessary to transport these minerals to bone cells. Therefore, silicon is an essential element for bone formation, and its deficiency negatively impacts bone development (Schwarz and Milne, 1972).

Some authors suggest that the bone mineral profile is the best response parameter for evaluating bone development and that mineral supplementation improves the locomotion system (Zhang and Coon, 1997; Teichmann et al., 1998; Ravindran et al., 1999). The linear increase in tibial ash content in the present experiment was probably due to the association between silicon supply and magnesium and phosphorus deposition in the long bones (Carlisle, 1981). An intrinsic relationship between silicon deposition and manganese and zinc deposition was not determined in the present study, but according to the data, the addition of silicon in the drinking water did increase tibial phosphorus and magnesium content. Sahin et al. (2006) supplied an arginine, silicon and inositol complex to quails subjected to heat stress and observed that calcium, phosphorus, magnesium and manganese content was reduced in the excreta and increased in the tibia. Therefore, consistent with this study, the availability of these minerals increased with the supplementation of silicon, as shown by their lower excretion (Sahin et al., 2006) and higher tibial deposition.

In conclusion, broiler performance was not impaired by adding the tested silicon product to the drinking water. In addition, bone development improved, as demonstrated by higher mineral and ash content. Additional studies are required to determine the optimal concentration of the evaluated silicon product in broiler drinking water, including heat stress simulations, in order to better understand the effects of silicon on bone development.

\section{DISCLOSURE STATEMENT}

No potential conflict of interest was reported by the authors.

\section{REFERENCES}

Almeida Paz, I.C.L., Mendes, A.A., Balog, A., Vulcano, L.C., Ballarin, A.W., Takahashi, S.E., Komyiama, C.M., Silva, M.C. \& Cardoso, K.F.G. (2008). Study on the bone mineral density of the femur of broilers suffering femur degeneration. Brazilian Journal of Poultry Science, 10 (2): 103-108.

Bissé, E., Epting, T., Beil, A., Lindinger, G., Lang, H. \& Wieland, H. (2005) Reference values for serum silicon in adults. Analytical Biochemistry, 337: 130-135. doi:10.1016/j. ab.2004.10.034

CARLisle, E.M. (1972) Silicon: An essential element for the chick. Science, 178: 619-621. doi:10.1126/science.178.4061.619

CARLisLe, E.M. (1981) A requirement in bone formation independent of vitamin $\mathrm{D}_{1}$. Science, 33: 27-34.

Clementi, G., Fiore, C.E. \& Mangano, N.G. (2001) Role of soy diet and L-Arginine in cyclosporin-a-induced osteopenia in rats. Pharmacology and Toxicology, 88: 16-19. doi:10.1034/ j.1600-0773.2001.088001016.x

Elliot, M.A. \& Edwards, H.M. (1991) Effect of dietary silicon on growth and skeletal development in chickens. Journal of Nutrition, 121: 201.

Fiore, C.E., Pennisi, P., Cutuli, V.M., Prato, A., Messina, R. \& Clementi, G. (2000) L-Arginine prevents bone loss and bone collagen breakdown in cyclosporin A-treated rats. European Journal of Pharmacology, 408: 323-326. doi:10.1016/S0014-2999(00)00800-1

Gough, J.E., Jones, J.R. \& Hench, L.L. (2004) Nodule formation and mineralisation of human primary osteoblasts 
cultured on a porous bioactive glass scaffold. Biomaterials, 25: 2039-2046. doi:10.1016/j.biomaterials.2003.07.001

Hing, K., Annaz, B., Saeed, S. \& Revell, P.T.B. (2005) Microporosity enhances bioactivity of synthetic bone graft substitutes. Journal of Materials Science: Materials in Medicine, 16: $467-475$.

Jugdaohsingh, R., Tucker, K.L., Qiao, N., Cupples, L.A., Kiel, D. P. \& Powell, J.J. (2004) Dietary silicon intake is positively associated with bone mineral density in men and premenopausal women of the Framingham Offspring cohort. Journal of Bone and Mineral Research, 19: 297-307. doi:10.1359/ JBMR.0301225

JunIOR, C.X. (2009) Deformidades das pernas em frangos de corte. Anais... Conferência APINCO de Ciência e Tecnologia Avícolas, Campinas, São Paulo, Brasil, pp. 29-41.

NäÄs, I.A., Baracho, M.S., Bueno, L.G.F., Moura, D.J., Vercelino, R.A. \& SAlgado, D.D. (2012). Use of vitamin $\mathrm{D}$ to reduce lameness in broilers reared in harsh environments. Brazilian Journal of Poultry Science, 14 (3): 159232.

Ravindran, V., Selle, P.H. \& Bryden, W.L. (1999) Effects of phytase supplementation, individually, and in combination, with glycanase, on the nutritive value of wheat and barley. Poultry Science, 78: 1588-1595. doi:10.1093/ps/78.11.1588

Rostagno, H.S., Albino, L.F.T., Donzele, J.L., Gomes, P.C., Oliveira, R.F., Lopes, D.C., Ferreira, A.S. \& Barreto, S.L.T. (2005) Tabelas brasileiras para aves e suínos: composição de alimentos e exigências nutricionais. 3rd edn. (Viçosa, UFV).
Sahin, K., Onderci, M., Sahin, N., Balci, T.A., Gursu, M.F., Juturu, V. \& Kucuk, O. (2006) Dietary arginine silicate inositol complex improves bone mineralization in quail. Poultry Science, 85: 486-492. doi:10.1093/ps/85.3.486

SAS Institute (2002) SAS ${ }^{\circledR}$ User's Guide: Statistics. (Cary, NC, Statistical Analysis System Institute).

SchWARZ, K. \& MiLnE, D.B. (1972) Growth promoting effects of silicon in rats. Nature, 239: 333-334. doi:10.1038/239333a0

Seaborn, C.D. \& Nielsen, F.H. (1994) Dietary silicon affects acid and alkaline phosphatase and ${ }^{45}$ calcium uptake in bone of rats. The Journal of Trace Elements in Experimental Medicine, 7: 11-18.

Silva, D.J. \& QueIroz, A.C. (2002) Análise de Alimentos: métodos químicos e biológicos. 3rd edn. (Viçosa, UFV).

Su, G., Sorensen, P. \& Kestin, S.C. (1999) Meal feeding is more effective than early feed restriction at reducing the prevalence of leg weakness in broiler chickens. Poultry Science, 78: 949-955. doi:10.1093/ps/78.7.949

Teichmann, H.F., López, J. \& López, S.E. (1998) Efeito da fitase na biodisponibilidade de fósforo em dietas com farelo de arroz integral para frangos de corte. Revista Brasileira de Zootecnia, 27: 338-344.

TUCKER, K.L. (2003) Dietary intake and bone status with aging. Current Pharmaceutic Design, 9: 2687-2704. doi:10.2174/ 1381612033453613

Zhang, B. \& Coon, C. (1997) The relationship of various tibia bone measurements in hens. Poultry Science, 76: 1698-1701. doi: $10.1093 / \mathrm{ps} / 76.12 .1698$ 